\title{
MANFAAT ALAT PEMBAYARAN MENGGUNAKAN KARTU (APMK) PADA MASYARAKAT KOTA TEGAL
}

\author{
Maulida Dwi Kartikasari \\ Fakultas Ekonomi dan Bisnis Universitas Pancasakti Tegal \\ Maulidadwikartikasari@upstegal.ac.id
}

\begin{abstract}
This research aims to find out the benefits of using the Card Payment Inatrument in Tegal. This research was conducted in the Tegal by taking 100 respondents to visitors shopping center in Tegal. The respondent despite into two groups, 50 male respondents and 50 female respondents this research use qualitative method. Respondents were randomly selected and the data were collected based on in depth interview results. The results of this research show that the Card Payment Method has a huge benefit for its users. Some societies state. able to bring cost-effective behavior because it can control spending. Of money. However, there are also people who give the perception that APMK is a secure payment instrument because mostly card has a Personal Indentification Number in it. Some of respondents sid that Card Payment Method are able to avoid the crime of counterfeit money
\end{abstract}

Keywords: Card Payment Instrument, Financial Behavior, Perception, Benefit

\section{A. PENDAHULUAN}

Alat pembayaran terus berkembang dari alat pembayaran tunai (cash banyak memakai uang kartal (uang kertas dan logam). Uang kartal masih berperan penting khususnya untuk transaksi yang bernilai kecil. Pemakaian uang kartal memiliki kendala dalam hal efisiensi. Hal itu bisa terjadi karena biaya pengadaan dan pengelolaan terbilang mahal dan belum lagi memperhitungkan efisiensi dalam waktu pembayaran. Selain itu transaksi dalam jumlah besar juga memiliki risiko terjadinya pencurian, perampokan, maupun pemalsuan uang.

Perkembangan teknologi di bidang informasi dan komunikasi telah memberikan dampak terhadap pembayaran non tunai dengan munculnya inovasiinovasi baru dalam pembayaran elektronis (electronic payment). Beberapa contoh pembayaran elektronik yang sudah dikenal di Indonesia saat ini antara lain phone banking, internet banking, Alat Pembayaran dengan Menggunakan Kartu (APMK) yaitu kartu kredit dan kartu debet/kartu ATM (Rahmatsyah, 2011). Pembayaran non tunai umumnya dilakukan tidak dengan menggunakan fisik uang (uang kartal) sebagai alat pembayaran melainkan dengan cara transfer antar bank ataupun transfer intra bank melalui jaringan internal bank sendiri.

Menurut definisi dari Direktorat Akunting dan Sistem Pembayaran Bank Indonesia Alat Pembayaran dengan Menggunakan Kartu (APMK) adalah alat pembayaran berupa kartu kredit, kartu Automated Teller Machine (ATM) dan/atau kartu debet. Saat ini, penyelenggaraan APMK diatur dalam PBI (Peraturan Bank Indonesia) Nomor 11/11/PBI/2009 dan PBI Nomor 14/12/PBI/2012 tentang penyelenggaraan kegiatan APMK. Sesuai ketentuan dalam peraturan Bank Indonesia No.7/52/PBI tahun 2005 tentang APMK, 
di masa depan dimungkinkan penerbit kartu prabayar multi purpose dapat berasal dari institusi non bank sehingga dipastikan komunikasi antara bank Indonesia dengan lembaga tersebut akan berjalan secara intens. Media komunikasi ini perlu disosialisasikan sehingga pihak-pihak terkait dapat memahami peran dan posisinya masing-masing

Kota Tegal merupakan salah satu kota pengguna APMK. Meskipun masih tergolong permulaan, namun masih menunjukkan peningkatan. Perkembangan zaman dan teknologi semakin banyak merubah tata cara kehidupan masyarakat Kota Tegal. Berbagai inovasi telah diciptakan untuk mempermudah berbagai transaksi jual beli. Munculnya sistem alat pembayaran menggunakan kartu telah secara nyata merubah dampak perekonomian. Hal ini didukung dengan semakin banyaknya perusahaanperusahaan ataupun pusat perbelanjaan di Kota Tegal yang menerima transakti pembayaran menggunakan kartu. Berikut data masyarakat Kota Tegal yang sebagai pengguna APMK.

Tabel 1.1

Pusat Perbelanjaan Penyedia Alat Pembayaran Menggunakan Kartu

\begin{tabular}{|l|l|l|l|}
\hline NO & \multicolumn{1}{|c|}{ NAMA } & \multicolumn{1}{|c|}{ PENERBIT } & \multicolumn{1}{c|}{ JENIS KARTU } \\
\hline 1 & Rita Mall & BNI, BRI, BCA, Mandiri & Debit, Kredit \\
\hline 2 & Pasifik Mall & $\begin{array}{l}\text { BNI, BRI, BCA, Bank Jateng, } \\
\text { Mandiri }\end{array}$ & Debit, Kredit \\
\hline 3 & Yogya Mall & BCA, Mandiri, Bank Jateng & Debit, Kredit \\
\hline 4 & Mini Market Kita & Mandiri & Debit, Kredit \\
\hline 5 & Alfamart & BCA, BNI, BRI & Debit, Kredit \\
\hline 6 & Indomaret & BCA, BNI & Debit, Kredit \\
\hline 7 & Mitra & BCA, Mandiri & Debit, Kredit \\
\hline
\end{tabular}

(sumber: hasil wawancara kasir pusat perbelanjaan, 2017)

Berdasarkan table 1.1 diketahui bahwa seluruh pusat perbelanjaan telah menyediakan alat pembayaran menggunakan kartu. Efisiensi sistem pembayaran dapat diukur dari kemampuan dalam menciptakan biaya yang minimal untuk mendapatkan manfaat dari suatu kegiatan transaksi. Pengguna jasa alat pembayaran menggunakan kartu akan menggunakan jasa alat pembayaran yang memiliki harga yang relatif lebih rendah sehingga biaya transaksi yang dikeluarkan juga rendah. Melalui penurunan biaya transaksi dan peningkatan kecepatan transaksi, inovasi pembayaran elektronik membuat alat pembayaran menggnakan kartu menjadi lebih efektif. Dari hasil informasi tersebut perlu diketahui seberapa besar manfaat APMK bagi masyarakat Kota Tegal.

\section{B. KAJIAN TEORI}

Segala upaya untuk mendorong dan mewujudkan masyarakat non tunai harus dibarengi dengan aturan yang jelas, yang memungkinkan semua pihak mengikuti kemajuan secara terstruktur demi mencapai menfaat penuh dari aktivitas ekonomi. berikut ini merupakan aturan yang berlaku di Indonesia

1. Peraturan bank Indonesia (PBI) Nomor 16/8/PBI/2014 tentang Perubahan Atas PBI Nomor 11/12/PBI/ 2009 tentang uang elektronik (Elektronik Money/E-Money).

2. PBI No.16/1/PBI/2014 tentang Perlindungan Konsumen Jasa Sistem Pembayaran.

3. PBI No.14/2/PBI/2012 tentang Perubahan Atas PBI Nomor 11/11/PBI/ 2009 tentang Penyelenggaraan 
Kegiatan Alat Pembayaran Dengan Menggunakan Kartu.

Sistem pembayaran terdiri atas unsurunsur sebagai berikut:

1. Politik/kebijakan yang dianut, bersifat normatif, menerangkan mengenai tujuan dan manfaat yang diharap.

2. Lembaga/organisasi yang terkait dalam sistem pembayaran

3. Sistem hukum yang berlaku

4. Alat-alat pembayaran yang lazim dan dinyatakan sah untuk dipergunakan.

\section{Karakteristik Masyarakat}

Karakteristik dari individu akan dihubungkan dengan perbedaan persepsi terhadap lingkungan. Hal tersebut sudah jelas akan melibatkan beberapa faktor antara lain kemampuan perseptual dan pengalaman atau pengenalan terhadap kondisi lingkungan. Kemampuan perseptual masing-masing individu akan berbeda-beda dan melibatkan banyak hal yang berpengaruh sebagai latar belakang persepsi yang keluar. Proses pengalaman dan pengenalan individu terhadap kondisi lingkungan yang dihadapi, pada umunya mempunyai orientasi pada kondisi lingkungan lain yang telah dikenal sebelumnya dan secara otomatis akan menghasilkan proses pembandingan yang menjadi dasar persepsi dihasilkan.

\section{Teori Perilaku Konsumen}

Mengenali perilaku konsumen tidaklah mudah, kadang mereka terus terang menyatakan kebutuhan dan keinginannya, namun sering pula mereka bertindak sebaliknya. Mungkin mereka tidak memahami motivasi mereka lebih mendalam, sehingga menit-menit terakhir sebelum akhirnya melakukan keputusan pembelian.1 Berikut ini adalah beberapa pengertian tentang perilaku konsumen menurut para ahli yaitu:

a. James F. Engel et al. (1968), berpendapat bahwa perilaku konsumen didefinisikan sebagai tindakan-tindakan individu yang secara langsung terlibat dalam usaha memperoleh dan menggunakan barang-barang jasa ekonomis termasuk proses pengambilan keputusan yang mendahului dan menentukan tindakan-tindakan tersebut.

b. Davis L. Loudon dan Albert J. Della Bitta (1984), mengemukakan bahwa perilaku kosumen dapat didefinisikan sebagai proses pengambilan keputusan dan aktivitas individu secara fisik yang dilibatkan dalam mengevaluasi, memperoleh, menggunakan atau dapat mempergunakan barangbarang dan jasa.

c. Gerald Zaltman dan Melanie Wallendorf (1979), menjelaskan bahwa perilaku kosumen adalah tindakan-tindakan, proses, dan hubungan sosial yang dilakukan oleh individu-individu, kelompok, dan organisasi dalam mendapatkan, menggunakan suatu produk atau lainnya sebagai dari pengalamannya dengan produk, pelayanan dan sumber-sumber lainnya.

d. Engel, Blackwell, dan Miniard (1995), mendefinisikan perilaku konsumen sebagai tindakan yang langsung terlibat dalam mendapatkan, mengkonsumsi, dan menghabiskan produk dan jasa, termasuk proses keputusan yang mendahului dan mengikuti tindakan ini.

e. Schiffman dan Kanuk (2010), mendefinisikan perilaku konsumen sebagai perilaku yang diperlihatkan konsumen dalam mencari, membeli, menggunakan, mengevaluasi, dan menghabiskan produk dan jasa yang mereka harapkan akan memuaskan kebutuhan mereka.

f. Dalam teori yang dikembangkan oleh Fishbein dan Ajzen (1975) tentang theory of reasoned action yang kemudian berkembang menjadi 
theory of planned behavior bahwa kontrol perilaku konsumen sangat menentukan minat dalam penggunaan suatu produk. Ada beberapa aspek dalam perilaku konsumen yang dapat mempengaruhi yaitu sikap, motivasi, kepercayaan, dan persepsi. Jika kesemua aspek tersebut mengarah secara positif maka minat dalam menggunakan uang elektronik akan menjadi signifikan.

Berdasarkan pengertian diatas, dapat disimpulkan bahwa perilaku konsumen adalah tindakan-tindakan yang dilakukan oleh individu, kelompok, atau organisasi yang berhubungan dengan proses pengambilan keputusan dalam mendapatkan, menggunakan barangbarang atau jasa ekonomis yang dapat dipengaruhi lingkungan. Perilaku pembelian konsumen adalah perilaku yang ditunjukkan konsumen dalam memilih dan memutuskan beberapa alternatif produk barang atau jasa untuk selanjutnya dibeli dan dimiliki. Studi perilaku konsumen adalah suatu studi mengenai bagaimana seorang individu membuat keputusan untuk mengalokasikan sumber daya yang tersedia (waktu, uang, usaha, dan energi).

Pada dasarnya perilaku konsumen merupakan perilaku yang berhubungan dengan usaha untuk mendapatkan produk guna memenuhi kebutuhannya. Sepanjang proses yang berawal dari timbulnya kebutuhan sampai pada keputusan beli, mengkonsumsi produk dan menyingkirkan produk bila sudah habis atau tidak digunakan lagi. Perilaku konsumen dipelajari agar lebih memahami tentang apa yang dibeli oleh konsumen, mengapa, dimana, kapan, dan seberapa sering dia membeli. Pengetahuan ini kemudian dipakai untuk menciptakan cara untuk memuaskan/memenuhi kebutuhan mereka dan menciptakan pendekatan yang baik untuk berkomunikasi dan mempengaruhi mereka.
Jadi, itu semua adalah kajiankajian yang sangat mendasar dalam seluruh kegiatan pemasaran. Sebagai pemasar, perilaku konsumen merupakan pegangan untuk benar-benar menjadikan dirinya digerakkan oleh pasar/konsumen, sehingga mustahil bila seorang pemasar atau ahli pemasar mengabaikan pengetahuan dan pemahaman tentang perilaku konsumen. Perilaku konsumen termasuk di antara deretan perilaku yang sangat cepat berubah, karena ia berkaitan dengan keseharian masyarakat dalam memenuhi kebutuhannya. Perubahan ini harus dapat ditangkap dengan baik supaya setiap permasalahan dalam perubahan tersebut dapat segera ditanggulangi.

Menurut Abraham Maslow terdapat tiga pendekatan utama dalam perilaku konsumen yaitu:

a. Pendekatan interpresif. Pendekatan ini menggali secara mendalam perilaku konsumsi dan hal yang mendasarinya. Studi dilakukan melalui wawancara panjang dan fokus group discussion untuk memahami apa makna sebuah produk dan jasa bagi konsumen dan apa yang dirasakan dan dialami konsumen ketika membeli dan menggunakannya.

b. Pendekatan tradisional yang didasari pada teori dan metode dari ilmu psikologi kognitif, sosial dan behaviorial serta ilmu sosiologi. Pendekatan ini bertujuan mengembangkan teori dan metode untuk menjelaskan perilaku dan pembuatan keputusan konsumen. Studi dilakukan melalui eksperimen tentang bagaimana seorang konsumen memproses informasi, membuat keputusan, serta pengaruh lingkungan sosial terhadap perilaku konsumen.

c. Pendekatan sebagai sains marketing yang didasari pada teori dan metode dari ilmu ekonomi dan statistika. Pendekatan ini dilakukan dengan 
mengembangkan dan menguji coba model matematika berdasarkan herarki kebutuhan manusia menurut Abraham Maslow untuk memprediksi pengaruh strategi marketing terhadap pilihan dan pola konsumsi yang dikenal dengan sebutan moving rate analysis. Ketiga pendekatan sama-sama memiliki nilai tinggi dan memberikan pemahaman atas perilaku konsumen dan strategi marketing dari sudut pandang dan tingkatan analisis yang berbeda. Sebuah perusahaan dapat saja menggunakan salah satu atau seluruh pendekatan, tergantung permasalahan yang dihadapi perusahaan tersebut.

\section{Penelitian Terdahulu}

Berdasarkan kajian yang dilakukan oleh Costa dan Grauwe (2001), penggunaan alat pembayaran non tunai secara luas memiliki implikasi pada berkurangnya permintaan uang terhadap uang yang diterbitkan oleh bank sentral, base money, yang pada gilirannya dapat mempengaruhi pelaksanaan tugas bank sentral dalam melaksanakan kebijakan moneter, khususnya pengendalian besaran moneter. Hal yang sama juga dikemukakan oleh Freidman (1999), perkembangan teknologi informasi akan memberikan implikasi terhadap berkurangnya peran base money dalam transaksi pembayaran.
Studi lain yang dilakukan oleh Woodford (2000) memiliki sudut pandang berbeda terhadap implikasi perkembangan alat pembayaran non tunai pada kebijakan moneter. Hasil studinya menunjukkan bahwa sekalipun uang kartal tersubstitusi oleh alat pembayaran non tunai kebijakan moneter tetap akan efektif. Bank sentral dalam hal ini tetap dapat mengontrol kebijakannya melalui tingkat suku bunga jangka pendek.

Bulut dan Koprulu (2010) melakukan penelitian mengenai kartu kredit pasar dan latar belakang sosio-ekonomi pemegang kartu kredit. Penelitian ini dilakukan di Turki dengan 450 sampel, melalui pembagian kuesioner dengan uji chisquare. Peneliti tersebut bertujuan untuk mengetahui karakteristik individu dalam memegang kartu kredit serta dampak karakteristik pada penggunaan kartu kredit. Indikator utama yang digunakan adalah usia, pendapatan per bulan, populasi, profesi, status pernikahan, pendidikan, kriteria pemilihan bank, serta tingkat suku bunga. Hasil penelitian menunjukkan bahwa status pernikahan, kemampuan membayar pemegang kartu.

\section{Kerangka Penelitian}

Berdasarkan kajian teori dan riwayat penelitian terdahulu di atas, kerangka penelitian yang dapat dirumuskan sebagai berikut:

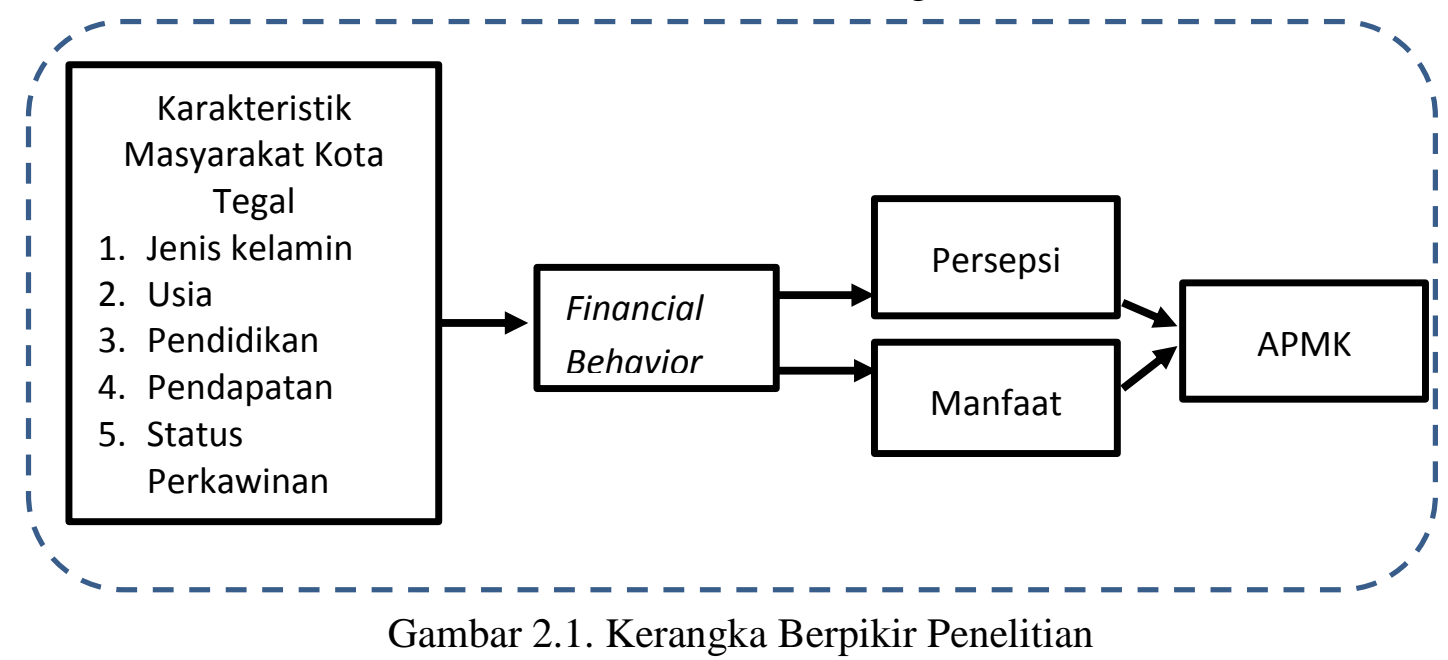




\section{METODE PENELITIAN}

Penelitian ini akan dilakukan di Kota Tegal, yaitu sebuah daerah di wilayah yang terletak di pesisir utara Pulau Jawa. Penentuan lokasi penelitian ditentukan dengan metode purposive sampling. Purposive sampling sendiri merupakan suatu penentuan lokasi penelitian secara sengaja berdasarkan atas pertimbangan-pertimbangan tertentu.

1. Desain Penelitian

Berdasarkan latar belakang masalah yang diangkat. Metode penelitian yang relevan untuk memecahkan research problem adalah metode kualitatif dengan desain fenomenologi. Menurut Husserl (Creswell, 1998) peneliti fenomenologis berusaha mencari tentang hal-hal yang perlu (esensial), struktur invarian (esensi) atau arti pengalaman yang mendasar dan menekankan pada intensitas kesadaran dimana pengalaman terdiri hal-hal yang tampak dari luar dan hal-hal yang berada dalam kesadaran masingmasing berdasarkan memori, image dan arti.

2. Sumber Data

a) Informan

Informan dalam penelitian ini adalah masyarakat di pusat perbelanjaan di Kota Tegal.

b) Fenomena Sosial

Fenomena sosial dalam penelitian adalah modernitas dalam bentuk perkembangan IPTEK berupa Alat Pembayaran Menggunakan Kartu.

3. Teknik Pengumpulan Data

Teknik pengumpulan data yang digunakan dalam penelitian ini adalah wawancara mendalam dan observasi partisipatif. Kedua teknik ini dinilai sebagai teknik yang paling efektif digunakan untuk menjawab permasalahan penelitian.

4. Validitas Data

Uji validitas data penelitian ini dilakukan menggunakan teknik trianggulasi dan member check. Teknik triangulasi dalam pengujian validitas, diartikan sebagai pengecekan data dari berbagai sumber dengan bermacam cara dan beragam waktu. Dengan demikian, triangulasi terdiri atas triangulasi sumber, triangulasi teknik pengumpulan data, dan triangulasi waktu. Triangulasi sumber dilakukan dengan cara mengecek data yang diperoleh melalui beberapa sumber. Data yang diperoleh dari beberapa sumber tersebut dideskripsikan, dikategorikan, dan akhirnya diminta kesepakatan (member check) untuk mendapatkan kesimpulan. Triangulasi teknik dilakukan dengan cara mengecek data pada sumber yang sama dengan teknik yang berbeda. Triangulasi waktu berkaitan dengan keefektifan waktu. Data yang dikumpulkan dengan teknik wawancara di pagi hari pada saat nara sumber masih segar dan belum banyak masalah akan memberikan data yang valid, sehingga lebih kredibel.

5. Teknik Analisis Data

Analisis data dalam penelitian ini menggunakan teknik analisis data interaktif. Dimana komponen reduksi data dan sajian data dilakukan bersamaan dengan proses pengumpulan data. Setelah data terkumpul, maka tiga komponen analisis (reduksi data, sajian data, penarikan kesimpulan) saling berinteraksi. Dalam kaitannya dengan penelitian ini, peneliti menggunakan metode analisis yang kedua yaitu model analisis interaksi (interactive analysis models) dengan 
langkah-langkah yang ditempuh yaitu sebagai berikut:

\section{HASIL PENELITIAN}

Kota Tegal secara wilayah administratif berbatasan langsung dengan Kabupaten Brebes dan Kabupaten Tegal. Sedangkan secara geografis kota Tegal terletak pada posisi $109^{\circ} 08^{\prime}$ - $109^{\circ} 10^{\prime}$ Bujur Timur dan 06 ${ }^{\circ} 50^{\prime}$ - 06 $6^{\circ} 53^{\prime}$ Lintang Selatan dengan luas wilayah yang relatif sempit bila dibandingkan dengan dengan wilayah sekitar yakni sebesar $39,68 \mathrm{Km}^{2}$ atau $0,11 \%$ dari luas Provinsi Jawa Tengah, setelah ada penambahan dari sebagian wilayah Kabupaten Brebes. Batas wilayah Kota Tegal secara administratif dapat diuraikan sebagai berikut: Sebelah Utara: Laut Jawa; Sebelah Timur: Kabupaten Tegal; Sebelah Selatan: Kabupaten Tegal; dan Sebelah Barat : Kabupaten Brebes.

Secara adminstratif Kota Tegal terbagi ke dalam 4 kecamatan dengan 27 Kelurahan. Kecamatan Tegal Barat memiliki wliayah paling luas sekitar $15,13 \mathrm{~km}^{2}$ disusul kecamatan Margadana seluas $11,76 \mathrm{~km}^{2}$, kecamatan Tegal Selatan seluas $6,34 \mathrm{~km}^{2}$ dan kecamatan Tegal Timur seluas $6,36 \mathrm{~km}^{2}$. Jumlah penduduk, perkembangan dan kepadatan penduduk di Kota Tegal menyebar hampir merata diseluruh wilayah kecamatan. Berdasarkan data Kota Tegal Dalam Angka tahun 2007 jumlah penduduk kota Tegal sebanyak 245.728 jiwa dengan kepadatan 6.193 jiwa $/ \mathrm{km}^{2}$. Jumlah penduduk terbanyak di wilayah kecamatan Tegal Timur sejumlah 73.641 jiwa dengan kepadatan 11.579 jiwa/ $/ \mathrm{km}^{2}$, sedangkan jumlah penduduk terendah di Kecamatan Margadana dengan jumlah 51.828 jiwa dan kepadatan 4.407 jiwa/ $\mathrm{km}^{2}$.

Kota Tegal, adalah salah satu kota di Provinsi Jawa Tengah. Kota ini berbatasan dengan Kabupaten Brebes di sebelah barat, Laut Jawa di sebelah utara, serta Kabupaten Tegal di sebelah timur dan selatan. Hari jadi kota Tegal adalah 12 April 1580. Kota Tegal juga merupakan cikal bakal kelahiran Korps Marinir TNI Angkatan Laut lahir pada 15 November 1945, seperti tercantum dalam Pangkalan IV ALRI Tegal nama Corps Mariniers. Status lembaga TNI AL di Tegal mengalami beberapa perubahan, mulai dari Detasemen AL (Denal), Landasan TNI AL (Lanal), dan Stasion AL (Sional). Untuk pertama kalinya, putra daerah yang menjabat sebagai Dan Sional adalah Letkol (Laut) Nurhidayat, asal Desa Kaligayam, kabupaten Tegal.

Perdagangan dan jasa merupakan sektor utama perekonomian kota Tegal. Kota ini menjadi tempat pengolahan akhir dan pemasaran berbagai produk dari kawasan Jawa Tengah bagian barat. Usaha kecil dan menengah yang cukup pesat kemajuannya adalah industri logam rumahan di kawasan jalan Cempaka, dan kerajinan batik Tegalan di kelurahan Kalinyamat. Untuk mendukung denyut perekonomian, pemerintah Kota Tegal telah membangun Pusat Promosi dan Informasi Bisnis (PPIB).

Iklim investasi yang cukup sejuk mengundang banyak investor luar daerah menanamkan modalnya di kota ini. Maka tak mengherankan, dalam kurun waktu 5 tahun sejak 2001, telah berdiri beberapa pusat perbelanjaan antara lain Pacific Mall, Rita Mall, Yogya Mall, Transmart Tegal, dan beberapa swalayan yang lain.

\section{Karakteristik Masyarakat Kota Tegal terhadap Penggunaan APMK.}

Berdasarkan hasil pelaksanaan kegiatan survey maupun diskusi dengan 100 pelaku pasar di pusat perbelanjaan Kota Tegal dapat disimpulkan bahwa 95\% masyarakat Kota Tegal telah mengenal dan memahami alat pembayaran menggunakan kartu. Saat ini 
alat pembayaran menggunakan kartu yang familiar digunakan masyarakat adalah kartu atm, kartu debet, dan kartu kredit. Adanya keberagaman jenis alat pembayaran mengggunakan kartu yang beredar di masyarakat, menyebabkan penggunanya dapat memilih sesuai dengan kemudahan-kemudahan yang ditawarkan. Sehinnga setiap pemilik dan pengguna alat pembayaran menggunakan kertu memiliki alasan tersendiri dalam memilih kartu.

Pandangan setiap orang sebagai pengguna alat pembayaran menggunakan kartu dapat berbeda-beda sesuai dengan karakteristiknya. Pada penelitian ini, karakteristik yang digunakan adalah usia, jenis kelamin, pendapatan, pendidikan, dan status pernikahan sesuai dengan penelitian yang dilakukan oleh Themba dan Turnedi, 2012.

Kedewasaan seseorang salah satunya dapat terlihat dari usianya. Berdasarkan hasil survey terhadap 100 pelaku pasar di pusat perbelanjaan Kota Tegal, terdapat 80 responden dengan usia 18-40 tahun. Rentangan usia merupakan masamasa dimana seseorang aktif bekerja dan beraktifitas, sehingga di usia tersebut paling banyak masyarakat menggunakan alat pembayaran menggunakan kartu. Bahkan dari 100 responden $78 \%$ atau 78 responden memiliki lebih dari 1 kartu untuk digunakan sebagai alat pembayaran.

Jenis kelamin akan menunjukkan perbedaan antara pria dan wanita dalam penggunaan APMK. Berdasarkan hasil survey sebanyak 50 wanita dan 50 pria ditemukan hasil bahwa $80 \%$ atau 40 responden pria sudah menggunakan APMK sedangkan $90 \%$ atau 45 responden wanita suka mengkoleksi berbagai jenis kartu. Sesuai dengan penelitian Burut dan Koprulu (2010) yang menyatakan bahwa seorang pria cenderung menyukai kartu kredit sedangkan wanita memiliki lebih dari 1 kartu sebagai alat pembayaran.

Pendapatan merupakan standar kemampuan seseorang dalam memenuhi kebutuhan hidupnya. Pendapatan menunjukkan pemasukan dana yang diperoleh dari pemegang kartu. Berdasarkan hasil survey sebanyak 100 responden, terdapat $87 \%$ atau sebanyak 87 responden dengan pendapatan diatas 3 juta rupiah. Adanya sistem pembayaran gaji melalui rekening bank menyebabkan seseorang lebih menyukai APMK dalam bertransaksi. Sesuai dengan penelitian Memalak, Memarista, dan Anastasia (2016) bahwa pengguna AMPK didominasi masyarakat dengan tingkat pendapatan diatas 3 juta rupiah.

Pendidikan menunjukkan pendidikan formal yang telah dilakukan seseorang. Berdasarkan hasil survey terdapat $42 \%$ atau sebanyak 42 responden lulusan SMA, 49\% atau sebanyak 49 responden lulusan sarjana, dan sisanya sebanyak 9\% atau 9 responden tidak menmpuh jenjang pendidikan formal terdapat kecenderungan seseorang yang menempuh pendidikan formal untuk menggunakan transaksi non tunai. Karena pengetahuan dari lingkungan sekitar, misalkan tawaran-tawaran dari pihak bank mengenai kemudahan-kemudahan dan keuntungan APMK baik di lingkungan kerja maupun lingkungan sekolah. Sesuai dengan penelitian Memalak, Memarista, dan Anastasia (2016) bahwa pengguna AMPK didominasi masyarakat dengan lulusan perguruan tinggi.

Status pernikahan merupakan status sosial yang sah secara hukum untuk mempunyai kehidupan berumah tangga. Berdasarkan hasil survey sebanyak 100 responden, terdapat $76 \%$ atau sebanyak 76 responden yang sudah memiliki status pernikahan. Dilihat dari status pernikahannya seseorang yang sudah menikah cenderung menggunakan 
APMK karena kembali ke sistem pembayaran gaji menggunakan media tabungan. Sedangkan seseorang yang belum menikah lebih suka memiliki lebih dari 1 kartu yang digunakan sebagai alat pembayaran. Sesuai dengan penelitian Bulut dan Koprulu (2010), seseorang yang telah menikah akan lebih sering menggunakan kartu kredit untuk memenuhi biaya kehidupan sehari-hari. Sedangkan, seseorang yang masih lajang akan mempunyai kartu kredit lebih banyak (Themba dan Turnedi,2012).

\section{Perilaku Mayarakat Kota Tegal terhadap APMK}

Financial Behavior menunjukkan perilaku manusia bertanggungjawab mengenai pengelolaan keuangan pribadi (Ida dan dwinta, 2010). Perilaku keuangan ini dapat dilihat melalui adanya pengelolaan keuangan yang bertanggungjawab dan dianggap mengalokasikan uang secara produktif. Perilaku ini mencerminkan adanya pembuatan anggaran untuk memastikan individu mampu mengelola kewajiban keuangan secara efektif. Perilaku keuangan dalam menggunakan APMK dapat ditinjau dari beberapa hal misalkan untuk pengguna kartu kredit, seberapa baikkkah seseorang dalam mengontrol keuangan dan seberapa tepat waktu kan seseorang dalam melunasi tagihan kartu kredit.

Keberagaman APMK yang beredar, menyebabkan konsumen memliki alasan yang beragam pula dalam memilih kartu yang akan digunakan. 67\% atau 67 responden menyatakan bahwa mereka menggunakan kartu sesuai dengan penerbit APMK gaji yang mereka peroleh. Selanjutnya $56 \%$ atau 56 responden menyatakan bahwa mereka menggunakan kartu yang lain disebabkan adanya promosi pihak penerbit kartu dengan penawaran berbagai keuntungan pada saat berbelanja. Faktor individu yang terdiri dari pendapatan, penge- luaran, dan investasi mempengaruhi seseorang dalam memilih dan menggunakan APMK.

Semakin tinggi kemampuan finansial seseorang, maka risiko yang ditanggung dalam memegang uang akan semakin besar. Oleh sebab itu, semakin tinggi kemampuan finansial seseorang, maka ada kecenderungan untuk menyimpan uangnya di bank dimana dianggap lebih aman. Sesuai dengan hasil survey kepada responden, bahwa seseorang dengan tingkat penghasilan diatas 3 juta lebih menyukai melakukan transaksi pembayaran menggunakan kartu dibandingkan dengan uang tunai. Perilaku tersebut muncul karena adanya keengganan untuk mengambil uang dari atm dan menyimpan langsung di rumah.

Namun ada perbedaan perilaku pada responden yang sudah berstatus kawin, mereka lebih menyukai melakukan transaksi menggunakan uang tunai. Dari 76 responden wanita yang sudah menikah, mereka mengungkapkan bahwa uang tunai dirasa lebih praktis, karena seiring kebutuhan dasar yang semakin meningkat misalnya, belanja sayur, belanja kebutuhan pokok, jajan anak-anak, serta kebutuhan dasar lainnya yang tidak bisa bertransaksi menggunakan APMK. Secara perilaku pada dasarnya wanita yang sudah menikah lebih menyukai transaksi menggunakan kartu, namun kondisi kebutuhan menyebabkan mereka harus menggunakan uang cash dalam bertransaksi.

James F. Engel et al. (1968), berpendapat bahwa perilaku konsumen didefinisikan sebagai tindakan-tindakan individu yang secara langsung terlibat dalam usaha memperoleh dan menggunakan barang-barang jasa ekonomis termasuk proses pengambilan keputusan yang mendahului dan menentukan tindakan-tindakan tersebut. Sesuai dengan hasil in dept interview pada 50 responden usia muda dan berpendidikan 
tinggi, mereka menyampaikan bahwa transaksi menggunakan kartu digunakan sebagai gaya hidup. Adanya APMK merubah tren pembayaran yang semula uang tunai menjadi APMK. Ada kecenderungan alasan trend dan gaya hidup yang menyebabkan berubahnya pola transaksi pembayaran.

Pada 50 responden wanita menyatakan bahwa dengan menggunakan APMK justru membuat mereka lebih dapat mengendalikan keinginan untuk berbelanja. Ada kecenderungan apabila memegang uang tunai seorang wanita akan menjadi lebih boros dibandingkan dengan memegang kartu. Selain itu kemudahan menjadi aspek penting bagi wanita dalam menggunakan APMK. Hal ini dikarenakan semakin mudah suatu hal digunakan maka minat dalam menggunakan hal itu akan menjadi semakin meningkat.

Karakterisstik individu yang meliputi jenis kelamin, usia, pendapatan, pendidikan, dan status pernikahan sangat mempengaruhi perilaku masyarakat dalam menggunakan kartu saat bertransaksi. Sesuai dengan penelitian Sridawati (2006) yang menyatakan adanya perubahan perilaku dalam penggunaan APMK adalah dipengaruhi oleh pendidikan, pengeluaran rata-rata per bulan, dan teknologi. Selain itu sejalan dengan penelitian Ahmed (2010) di Malaysia. Pada masyarakat yang sudah menikah cenderung menggunakan APMK untuk membeli kebutuhan layanan bahan bakar (bensin), pakaian, dan kesehatan. Untuk pembelian ritel, pengguna mengalokasikan sebagian besar untuk akomodasi/hotel, makan dan bahan belanja. Hal ini menunjukkan ada hubungan yang positif antara karakteristik masyarakat dengan tingkat penggunaan APMK.
Persepsi dan Manfaat APMK terhadap Masyarakat Kota Tegal

Informasi mengenai persepsi, preferensi, dan manfaat APMK terhadap masyarakata Kota Tegal diperoleh data berdasarkan wawancara langsung dengan responden. Secara umum, pada dasarnya masyarakat sudah sangat familiar dengan masyarakat. Alat pembayaran yang sudah sering digunakan masyarakt adalah kartu debet dan kartu kredit. Untuk alat pembayaran berbasis online seperti ovo, dana, gopay daan lain sebagainya masyarakat kurang familiar dan merasa kurang efisien karena harus isi ulang terlebih dahulu. APMK merupakan instrumen yang berfungsi selain untuk tarik tunai juga sebagai alat pembayaran.

Alasan masyarakat menggunakan APMK adalah karena adanya keengganan untuk memegang uang tunai terlalu banyak, sehingga hal tersebut mendorong dan sebagai motivasi masyarakat dalam penggunaan APMK, selain itu alasan kemudahan, keamanan, dan efisiensi menjadi persepsi masyarakat terhadap APMK. Secara umum, masyarakat pengguna APMK didominasi oleh seseorang dengan karakteristik terbuka terhadap informasi baru, orang yang berpikir sebagai leader atau pelopor bagi orang lain dan memang tipe orang yang menyukai model pembayaran non tunai.

Persepsi para pengguna APMK berpendapat bahwa pengembangan instrumen non tunai perlu memperhatikan beberapa aspek penting seperti, budaya masyarakat, kebutuhan, dan perilaku penggunanya. Aspek lain yang perlu disoroti oleh penerbit APMK adalah faktor kemudahan, kenyamanan, keamanan secara teknologi (terhindar dari hacker), praktis, dan cepat. Disamping itu, pemenuhan lebutuhan pembayaran menggunakan kartu yang disediakan oleh hampir seluruh pusat perbelanjaan di Kota Tegal cukup 
bersinergi dan memegang peranan penting terhadap pengguna APMK. Sesuai dengan penelitian Hidayat (2006) bahwa masyarakat memanfaat $e$-money karena kemudahan, efisiensi, serta kemaanan yang diperoleh dalam menggunakannya.

E-money berpotensi untu lebih berkembang lagi. Bukti ini dapat terlihat dari 100 responden masyarakat Kota Tegal, $70 \%$ diantaranya telang menggunakan memanfaatkan transaksi $E$ money dengan bertransaksi menggunakan kartu baik debit maupun kredit. Alasan kesediaan masyarakat dalam memanfaatkan e-money adalah kemudahan, kenyamanan, kemanan, dan maysrakat berpersepsi bahwa e-money mampu menekan pengeluaran konsumtif. Adanya beberapa pihak pusat perbelanjaan yang tidak menyediakan fasilitas e-money diyakini sebagian respoden wanita mampu menekan pengeluaran konsumsi. Keengganan merekan dalam mengambil uang di ATM membuat seseorang menggagalkan rencana keputusan pembelian suatu barang.

Selain alasan kemudahan ada kecenderungan masyarakat menyukai produk baru yang sedang tren seperti $e$ money. alasan prestise juga mendominasi sebagaian responden terhadap penggunaan APMK. Hal ini sejalan dengan Penelitian yang dilakukan oleh Yudhistira (2014) yang berjudul Analisis Faktor yang Mempengaruhi Preferensi dan Aksesibilitas terhadap Penggunaan Kartu Pembayaran Elektronik dengan variabel independen kepemilikan kartu, manfaat kartu, daya tarik kartu, kerugian kartu, informasi tentang kartu, syarat mendapatkan kartu dan teknologi dalam system pembayaran, sedangkan penggunaan kartu pembayaran elektronik sebagai variabel dependen. Hasil dari penelitian ini menunujukkan bahwa manfaat yang diperoleh menjadi faktor terbesar yang mempengaruhi preferensi nasabah menggunakan kartu pembayaran elektronik, informasi terhadap penggunaan teknologi dalam kartu pembayaran elektronik menjadi faktor terbesar aksesibilitas nasabah.

Manfaat kemudahan dirasakan karena responden menganggap bahwa bahwa empat indikator persepsi kemudahan yaitu mudah dan nyaman untuk dibawa, fleksibelitas, mempermudah dalam mengontrol transaksi pembayaran dan mudah untuk digunakan sangat dirasakan oleh responden ketika menggunakan kartu ATM atau kartu debit. Selain itu responden yang sudah menikah memiliki karakteristik lebih mudah berinteraksi sosial di lingkungan masyarakat yang tinggi ditambah dengan pola kehidupan di masyarakat yaitu berkaitan dengan interaksi terhadap tetangga sekitar tempat tinggal yang juga memiliki interaksi sosial tinggi, sehingga hal ini mengakibatkan apapun keputusan yang akan diambil oleh responden akan mempertimbangkan pendapat dari orang di sekitarnya, begitu juga dalam hal penggunaan APMK.

Namun demikian ada perbedaan persepsi pada masyarakat pengguna APMK namun berpenghasilan 1-3 juta. Hal tersebut dikarenakan karakterisktik dari resonden rata-rata berpenghasilan sebesar 1-3 juta dengan pekerjaan sebagai karyawan. Dengan gaji tersebut, responden akan cenderung menghabiskan gaji tersebut untuk memenuhi kebutuhan pokok, di mana hal ini mengakibatkan kartu ATM/kartu debit kurang mendapatkan perhatian., sehingga akhirnya kartu ATM/kartu debit kurang dimanfaatkan secara maksimal. Hal tersebut sejalan dengan penelitian Khakim (2014) yang menyatakan adanya persepsi kemudahan, kemanfaatan, dan pengaruh lingkungan sosial terhadap penggunaan APMK. 


\section{E. SIMPULAN}

Alat pembayaran terus berkembang dari alat pembayaran tunai (cash based) ke alat pembayaran non tunai (non cash). Alat pembayaran tunai lebih banyak memakai uang kartal (uang kertas dan logam). Uang kartal masih berperan penting khususnya untuk transaksi yang bernilai kecil. Pemakaian uang kartal memiliki kendala dalam hal efisiensi. Hal itu bisa terjadi karena biaya pengadaan dan pengelolaan terbilang mahal dan belum lagi memperhitungkan efisiensi dalam waktu pembayaran. Selain itu transaksi dalam jumlah besar juga memiliki risiko terjadinya pencurian, perampokan, maupun pemalsuan uang.

Alat Pembayaran Menggunakan Kartu (APMK) memiliki manfaat yang sangat besar bagi para penggunanya. Pengguna APMK berada di kisaran usia 18-40 tahun. Penggunanya sebagian besar wanita, memiliki penghasilan diata Rp 3 juta, serta seudah berumah tangga. APMK memiliki manfaat efektif dan salah satu cara untuk mengendalikan pembelanjaan bagi penggunanya.

\section{Saran}

Peneliti menyadari bahwa selesainya penelitian ini masih menyisahkan berbagai persoalan tentang objek penelitian. Penelitian berikutnya akan dikembangkan lebih luas lagi yaitu pembahasan mengenai alat pembayaran non tunai lainnya. Selain itu, persepsi akan lebih spesifik lagi yaitu pembahasan mengenai persepsi masyarakat muslim.

\section{DAFTAR PUSTAKA}

Abraham H. Maslow, 2010, Motivation and Personality. Rajawali, Jakarta.

Ahmed, Z. U., Ismail, I., Sohail, M. S., Tabsh, I. dan Alias, H. 2010. Malaysian Consumers' Credit Card Usage Behavior. Asia Pacific Journal of Marketing and Logistics, 22(4), 528-544

Bank Indonesia, 2006. Persepsi, Preferensi dan Perilaku Masyarakat dan Lembaga Penyedia Jasa Terhadap Sistem Pembayaran Non Tunai. Penelitian Bank Indonesia. Diakses Tanggal 15 September 2018 Pukul. 20.20.

Bank Indonesia, 2009. Peraturan Bank Indonesia No 11/11/PBI/2009 Tentang Alat pembayaran Dengan Menggunakan Kartu.

Bank Indonesia, 2013. Laporan Sistem Pembayaran dan Pengelolaan Uang 2012. Departemen Akunting dan Sistem Pembayaran Departemen Pengelolaan Uang. Diakses tanggal 15 September Pukul 20.20.

Bulu, Y. dan Koprulu, O. 2010. Credit Card Market and Socio-Economic Background of Card Holders: A Case Study from Turkey. International Journal of Economic Perspectives. Vol. 4. Issue 4. Page 623-633.

Gordon B. Davis. 1998. Kerangka dasar Sistem Informasi Manajemen: Pengantar Seri Manajemen No: 90. A, PT. Pustaka Binaman Pressindo.Surabaya

Engel, J. F, R. D. Blackwell, P.W. Miniard. 1995. Perilaku Konsumen, Balai Pustaka, Jakarta. 
Gerald Zaltman and Melanie Wallendorf. 1971. Consumer Behavior: Basic Findings and Management Implications. The United State of America: By John Willey and Sons Inc. 378 hal.

Hidayat, Adi. 2006. Upaya Meningkatkan Penggunaan Alat Pembayaran Non Tunai Melalui Pengembangan E-Money. Working Paper Bank Indonesia.

Humprey, David B, 1995. Payment Systems: Principles, Practice, and Improvement. Washington, D.C.: The World Bank. Diakses tanggal 10 Januari 2019 Pukul 14.16 WIB.

Ida dan Dwinta, C.Y. 2010. Pengaruh Locus of Control, Financial Knowledge, Income, dan Financial Management Behavior. Jurnal Bisnis dan Akuntansi. Vol 12. No . 131-144.

Khakim. 2014. Pengaruh Persepsi Kemudahan, Persepsi Kemanfaatan Dan Kelompok Referensi Terhadap Penggunaan Alat Pembayaran Menggunakan Kartu (APMK) (Studi Kasus Masyarakat Kabupaten Grobogan). Diakses tanggal 10 Januari 2019 Pukul 14.16 WIB.

Laurens, Joyce Marcella, 2004, Arsitektur dan Perilaku Manusia, Grasindo, Jakarta.

Patton, MQ. 2009. Metode Evaluasi Kualitatif. Jakarta: Pustaka Pelajar.

Rahmatsyah, Deni, 2011. Analisis Faktor-Faktor yang mempengaruhi Minat Penggunaan Produk Baru (studi kasus: E-Money Flash BCA tahun 2011). Tesis. Universitas Indonesia

Schiffman, Leon G dan Leslie, Lazar Kanuk. 2008. Perilaku Konsumen. PT. Indeks. Jakarta. 522 hal.

Suharsimi Arikunto, 2002. Prosedur Penelitian: Suatu pendekatan Praktek (Jakarta: PT Rhineka Cipta).

Sridawati. (2006). Analisis Faktor-Faktor yang Mempengaruhi Preferensi Masyarakat Terhadap Penggunaan Kartu Pembayaran Elektronik.

Themba, G., \& Tumedi, C. B. 2012. "Credit Card Ownership and Usage Behaviour in Botswana." International Journal of Business Administration.

Woodfoord, Michael, 2000. "Monetary Policy In A World Without Money”, National Bureau of Economic. Research Working Paper, Nomor 7853. Diakses tanggal 10 Januari 2019 Pukul 14.42 WIB.

Yudhistira, Afrizal. 2014. "Analisis Faktor yang Mempengaruhi Preferensi dan Aksesibilitas terhadap Pengguanaan Kartu Pembayaran Elektronik" Diakses tanggal 10 Maret 2019 Pukul 14.42 WIB. 